\title{
S25C および SUS304 の同種材摩擦圧接における温度分布の数值解析 \\ Numerical Analysis of Temperature Distribution in Friction Welding of Two Similar Materials of S25C or SUS304
}

\author{
一色美博* - 山口 博**. 川井五 作***. 越智 秀****. 小川恒 - ** \\ Yoshihiro ISSHIKI, Hiroshi YAMAGUCHI, Gosaku KAWAI, Hiizu OCHI and Koichi OGAWA
}

(Received April 24, 2006)

\begin{abstract}
An approach to combine a friction heat input model with a non-steady heat conduction analysis has enabled a numerical simulation of a heat input and a transient temperature distribution in friction welding processes. This report describes the result obtained by applying this approach to the friction welding process of two similar materials of S25C carbon steel or SUS304 stainless steel. When base metals are different, the friction heat input model and the thermophysical property data are changed depending on a quality of base metal. Comparison between a calculated result and an experimental result was carried out, and appropriateness of this approach was examined. Furthermore, a difference of temperature distribution in friction welding region with the difference of thermophysical property of base metal was examined, and also the heat-affected zone was investigated. As a result, it was verified that this approach could simulate a characteristic of a welding process in brake-type friction welding. And the calculated results agreed with the experimental results on a difference of quantity of heat input to be caused by a difference of a friction welding condition. A difference of a temperature history caused in a different base metal appeared to be estimated from a calculated result, and it was confirmed that this approach was appropriate. The width of heat-affected zone was estimated by an calculated result of the maximum temperature distribution in the vicinity of friction surface by using this approach combining a friction heat input model with a non-steady heat conduction analysis.
\end{abstract}

Key Words: Friction Welding, Friction Heat Input, Transient Temperature Distribution, Heat-Affected Zone, Finite-Element Analysis

\section{1. 緒言}

摩擦圧接法は接合に要するエネルギーが少なく短時間で接 合できるため，その用途が拡大している1)。一方，その圧接 条件は一般に過去の経験や研究報告などに基づいて選定され ることが多く, 圧接現象に対応した選定方法の確立が求めら れている。この種の問題に関して, 摩擦圧接時の機械的仕事 によって生じる熱量すなわち入熱で継手の機械的性質を整理 する試みがなされており ${ }^{2)}$ ，アプセット過程における入熱が 継手の静的強度に大きく関わっていることが明らかとなっ

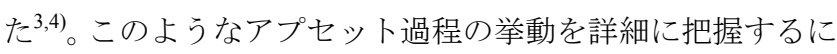
は, 摩擦圧接時の圧接部における温度履歴を知ることが重要 と考えられる。そこで著者らは，アプセット過程における圧 接部過渡温度分布の推定を目的として, 摩擦入熱に関する簡
易モデルを構築するとともに有限要素法による非定常熱伝導 解析を行う方法を提案し, これを炭素鋼の摩擦圧接に適用し てその妥当性を検証した ${ }^{5)}$ 。この方法は圧接圧力と回転速度 のデータおよび母材の熱物性データを基に圧接過程の伝熱解 析を行うので, 大部分の生産用圧接機のようにトルク測定が できない場合においても圧接部の温度分布を推定することが できるが，母材の材質が異なる場合，摩擦入熱モデルと熱物 性データを母材に応じて変更する必要がある。

本報告では, 前報 ${ }^{5)}$ の $\mathrm{S} 25 \mathrm{C}$ 炭素鋼同種材摩擦圧接の解析 に加え, SUS304 ステンレス鋼同種材の摩擦圧接にも本方法 を適用できるように摩擦入熱モデルと熱物性データを変更し て解析を行い, 実験結果と比較してその妥当性を確認すると ともに母材の熱的性質の違いによる圧接部温度分布の差異お よび熱影響部について検討した。

\footnotetext{
*摂南大学工学部( ( $572-8508$ 寝屋川市池田中町 17-8)

Faculty of Engineering, Setsunan University (17-8 Ikedanakamachi, Neyagawa, Osaka 572-8508, Japan)

**大阪府立大学総合教育研究機構 ( $7599-8531$ 堺市学園町 1-1)

Faculty of Liberal Arts and Sciences, Osaka Prefecture University (1-1 Gakuencho, Sakai, Osaka 599-8531, Japan)

$* * *$ 大阪産業大学工学部( $5574-8530$ 大東市中垣内 3-1-1)

Faculty of Engineering, Osaka Sangyo University (3-1-1 Nakagaito, Daito, Osaka 574-8530, Japan)

****大阪工業大学リエゾンセンター( 5 535-8585 大阪市旭区大宮 5-16-1)

Liaison Center, Osaka Institute of Technology (5-16-1 Omiya, Asahi-ku, Osaka 535-8585, Japan)
} 


\section{2. 実験方法}

摩擦圧接の実験にはブレーキ式摩擦圧接機を用いた。供試 材は S25C 炭素鋼（熱間圧延）とSUS304 ステンレス鋼（冷 間引抜き）であり，直径 $20 \mathrm{~mm}$ の供試材を長さ $80 \mathrm{~mm}$ （回 転側）と $200 \mathrm{~mm}$ (静止側）に切断したものを圧接母材とし た。圧接部近傍の過渡温度分布を測定するため, 静止側母材 の摩擦面からの軸方向距離 $2.5 \mathrm{~mm}$ と $6.5 \mathrm{~mm}$ の位置に, 直径 $3 \mathrm{~mm}$, 深さ $5 \mathrm{~mm}$ の穴をあけた試験片を作成し, 各々の穴底 に素線径 $0.32 \mathrm{~mm}$ のガラス被覆クロメル・アルメル熱電対 を溶接した。また，摩擦トルクを測定するため，摩擦面から 約 $40 \mathrm{~mm}$ の位置に $90^{\circ}$ 交叉 2 軸歪みゲージを母材表面に貼 付した。用いた圧接条件を Table 1 に示す。なお，今回の実 験では摩擦圧接時の入熱および温度分布の調査を主眼として いるので, 圧接圧力は通常の圧接条件より低く設定してある。 実験においては温度, 摩擦トルクのほか, 光学式非接触回転 計にて摩擦速度, ポテンショメータにて寄り代, 圧力変換器 にて圧接圧力を各々検出し, サンプリング周期 $10 \mathrm{~ms}$ にてメ モリレコーダに逐次記録した。

\section{3. 数値解析方法}

摩擦圧接時の温度分布の数值解析には有限要素法を用いた。 同種材の圧接であるので，解析領域は Fig.1 に示すように片 側の母材のみとし, 直径 $20 \mathrm{~mm}$, つかみ部を含む長さ $140 \mathrm{~mm}$ の範囲を半径方向に 4 分割, 軸方向に 46 分割した。初期の 母材温度を $20{ }^{\circ} \mathrm{C}$ とし, 摩擦開始からアプセット圧力負荷 後までの二次元軸対称非定常熱伝導の計算を行った。摩擦面 には後述の摩擦入熱モデル5)で計算される熱流束を与える。 つかみ部に対応する母材側面の温度は $20{ }^{\circ} \mathrm{C}$ に固定し, つ かみ部以外の側面では熱伝達および熱放射による放熱を考慮 した。解析に用いた S25C と SUS304 の比熱 $c\left(\mathrm{~kJ}^{\circ} \mathrm{kg}^{-1} \cdot \mathrm{K}^{-1}\right)$

Table 1 Friction welding conditions.

\begin{tabular}{cc|c|c|c|c}
\hline \multicolumn{2}{c|}{ Condition } & $\mathrm{C} 1$ & $\mathrm{C} 2$ & $\mathrm{C} 3$ & $\mathrm{C} 4$ \\
\hline Friction pressure & $P_{1}(\mathrm{MPa})$ & 30 & 15 & 15 & 15 \\
\hline Upset pressure & $P_{2}(\mathrm{MPa})$ & 100 & 100 & 100 & 100 \\
\hline Friction time & $t_{1}(\mathrm{~s})$ & 10 & 10 & 5 & 2.5 \\
\hline Rotation speed & $N\left(\mathrm{~s}^{-1}\right)$ & 50 & 50 & 50 & 50 \\
\hline
\end{tabular}

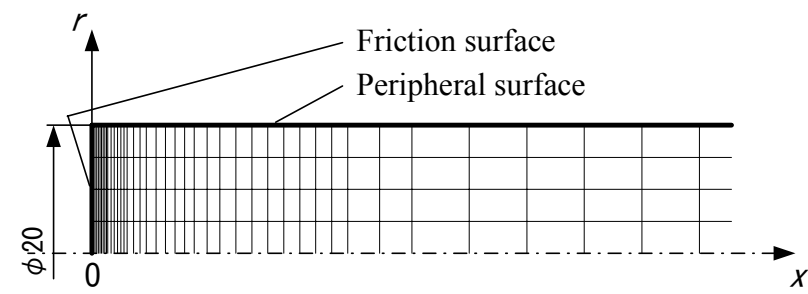

Fig.1 Mesh data of specimen.
および熱伝導率 $\lambda\left(\mathrm{W} \cdot \mathrm{m}^{-1} \cdot \mathrm{K}^{-1}\right)$ を Fig.2 に示す。なお，物性 データ ${ }^{6}$ が明らかでない温度範囲においては図中の破線で示 すように, 既知の限界温度に相当する值を近似值として用い た。実際の摩擦圧接においては時間の経過とともに母材の形 状が変化し，その一部がバリとして外部に排出される。特に アプセット過程では母材の変形は大きいが, 摩擦過程, アプ セット過程を通して母材の変形による入熱は摩擦入熱に比心゙ てかなり小さいので7), ここでは変形入熱は無視した。また, 解析を簡単にするため, 母材の形状は変化しないものとして 取り扱い，バリの排出による熱の流出は無視している。

摩擦入熱に関しては摩擦面に作用する摩擦力から算出する。 Fig.3 に示す摩擦面内の微小半径領域 $\Delta r_{e}$ の要素 $\mathrm{e}$ における単 位時間あたりの摩擦入熱 $q_{e}(\mathrm{~W})$ は, 摩擦力を $F_{e}(\mathrm{~N})$, 線速 度を $v_{e}=2 \pi r_{e} N\left(\mathrm{~ms}^{-1}\right)$ とすれば式(1)で表される。

$$
q_{e}=F_{e} \cdot v_{e}
$$

ここで, $r_{e}(\mathrm{~m})$ は半径, $N\left(\mathrm{~s}^{-1}\right)$ は摩擦速度である。摩擦力 $F_{e}$ は半径位置と時間の関数であり, 摩擦面に作用する局所圧 力と摩擦面の状態によって変化する。ここでは摩擦応力が見 掛けの摩擦係数 $\mu_{e}$ と摩擦面にはたらく平均の圧力である摩 擦圧力 $P_{f}(\mathrm{~Pa})$ の積で表されると仮定し, 次式で摩擦力を与 える。

$$
F_{e}=\mu_{e} \cdot P_{f} \cdot 2 \pi r_{e} \Delta r_{e}
$$

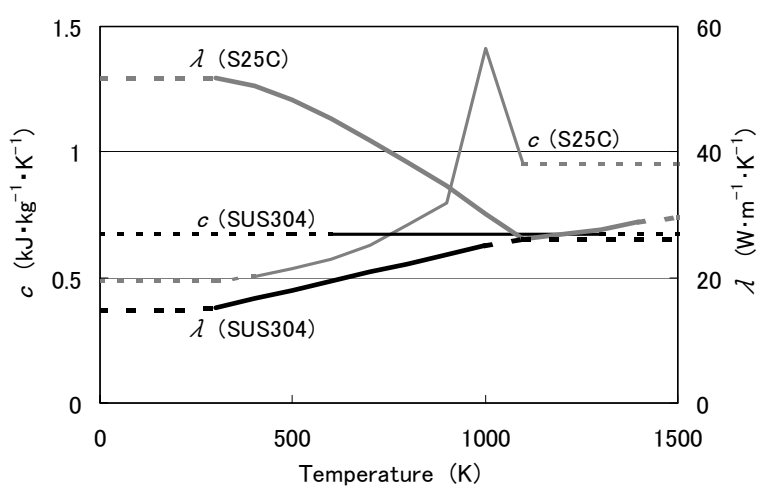

Fig.2 Specific heat and thermal conductivity of S25C carbon steel and SUS304 stainless steel.

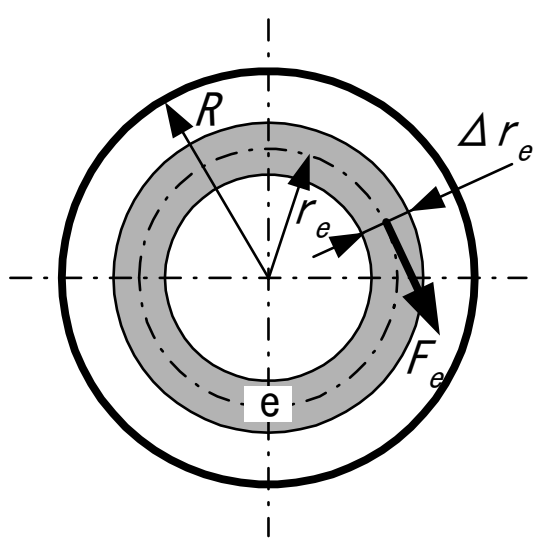

Fig.3 Elementary area on friction surface. 
$\mu_{e}$ は摩擦面における分子結合の形成と破壊に関連する係数 と考えられ，理論的に与えることは困難であるが， $\mu_{e}$ と線 速度の関係に関しては実験的に式(3)が提案されている ${ }^{8)}$ 。

$$
\mu_{e}=\frac{A}{v_{e}^{k}}
$$

ここで， $A, k$ は経験的に定まる係数である。係数 $k$ につい ては，母材の材質に無関係に文献 ${ }^{8)}$ で提示されている一定值 1.7 を用いた。また，S25C に対する係数に関しては，前 報5) と同様 $A=5.4$ とするが, SUS304 に対しては, S25C に比 ベSUS304 の摩擦トルクが小さいことから，Table 1 の各条 件で実施した実験結果をもとに係数值を修正し $A=3.1$ とし た。さらに，見掛けの摩擦係数 $\mu_{e}$ は温度の影響も受けると 考えられるので, これが母材の変形抵抗の温度依存性 ${ }^{9,10)}$ と 同様に変化すると仮定し, S25C と SUS304 の $\mu_{e}$ を各々

Fig.4(a), Fig.4(b)のように与えた。なお，式(3)において $k>0$ の場合, 線速度が小さい領域で $\mu_{e}$ は増大するが，摩擦応力 が母材のせん断強さを越えることはないので $\mu_{e} \cdot P_{f} \leq \tau_{\text {lim }}$ な る制約条件を加えた。ここで， $\tau_{\text {lim }}(\mathrm{Pa})$ は上限のせん断応力 であり，母材のせん断強さに対応するがこの值も変形抵抗の 温度依存性と同様に変化すると仮定した。また，母材温度が 融点（S25C では $1530{ }^{\circ} \mathrm{C}, \mathrm{SUS} 304$ では $1410{ }^{\circ} \mathrm{C}$ ）に達した 場合，摩擦力は無視できると考え $\mu_{e}$ を 0 とした。

\section{4. 実験結果および解析結果}

4. 入熱と温度分布

Table 1 に示寸各々の摩擦圧接条件について, S25C 炭素鋼 およびSUS304 ステンレス鋼の圧接圧力と回転速度の実測デ 一タを用いて数值計算を行った。実験結果の一例として, 摩 擦圧力 $P_{1}=30 \mathrm{MPa}$, 摩擦時間 $t_{1}=10 \mathrm{~s}$ （条件 C 1）における圧 接圧力と摩擦速度の測定值を Fig.5, 摩擦トルクと寄り代の 測定值を Fig.6 に示す。Fig.6(a), Fig.6(b)に示されるように， S25C, SUS304 ともにトルクは摩擦開始直後に急激に増大し て最大トルクが発生し, その後徐々に低下して定常状態に至 り，アプセット過程で再度大きくなる。SUS304 の摩擦圧力

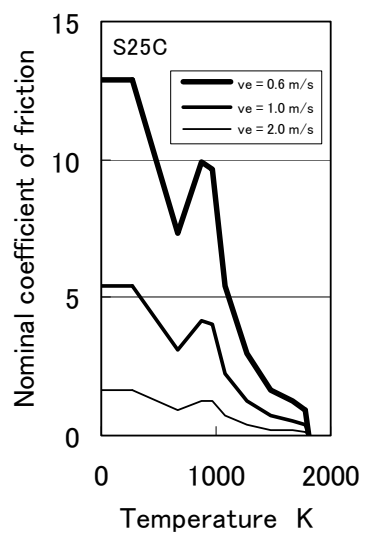

(a)

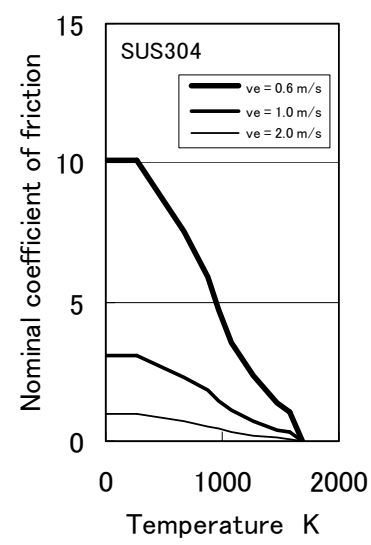

(b)
Fig. 4 Nominal coefficient of friction: (a) S25C and (b) SUS304.

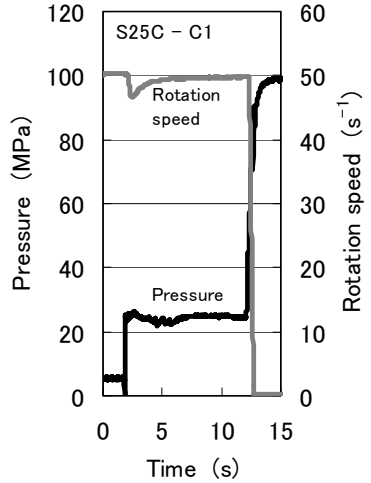

(a)

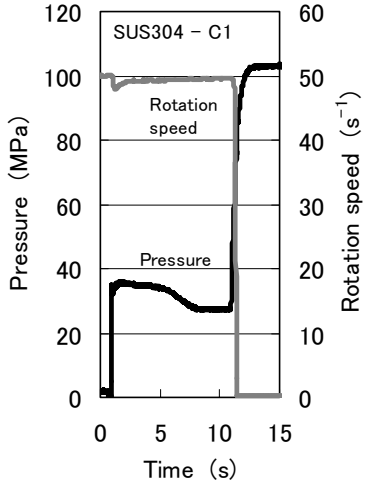

(b)
Fig. 5 Variations in pressure and rotation speed with time: (a) S25C-C1 and (b) SUS304-C1.

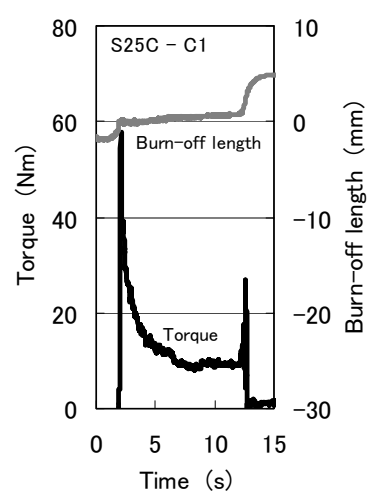

(a)

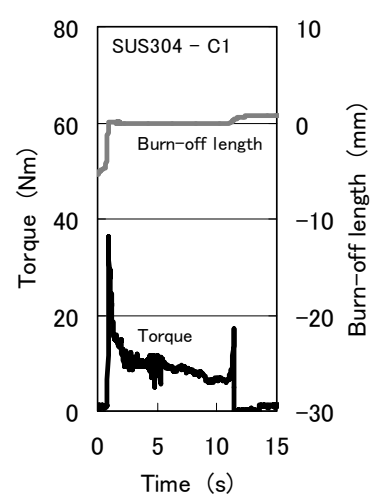

(b)
Fig. 6 Variations in torque and burn-off length with time: (a) S25C-C1 and (b) SUS304-C1.

の実測值は S25C に比べ若干高いにもかかわらず, SUS304 のトルクは S25C に比較して小さく, また, SUS304 の寄り 代が S25C よりかなり小さいなど，母材の材料特性の差が現 れている。

摩擦圧力 $P_{1}=30 \mathrm{MPa}$, 摩擦時間 $t_{1}=10 \mathrm{~s}$ (条件 C1), $P_{1}=15$ $\mathrm{MPa}$ ，摩擦時間 $t_{1}=5 \mathrm{~s}$ （条件 C3）における摩擦トルクおよび 摩擦速度の実験值から求めた摩擦入熱と数值計算で得られた 摩擦入熱を S25C について Fig.7, SUS304 について Fig.8 に 各々示す。なお, 実験における摩擦入熱の計算では摩擦仕事 から熱への変換効率を 1 とした ${ }^{7)}$ 。Fig.7 において, 摩擦開始 直後に現れる摩擦入熱のピーク值は, 条件 $\mathrm{C} 1$ の実験值, 計 算值が各々 $9.2 \mathrm{~kW}, 10.4 \mathrm{~kW}$, 条件 C3 の実験值, 計算值が 7.7 kW, 5.4 kW であり, Fig.8 については, 条件 C1 の実験 值, 計算值が $5.7 \mathrm{~kW}, 8.7 \mathrm{~kW}$, 条件 C3 の実験值, 計算值が $4.0 \mathrm{~kW}, 5.0 \mathrm{~kW}$ である。実験では接合端面の性状が多少ばら つき，圧接開始直後の入熱にその影響が大きく現れるため， 入熱のピーク值の実験結果と計算結果が大きく異なる場合も あるが, 両材質の入熱の数值計算結果には摩擦開始直後の入 熱のピークや摩擦時間 $t_{1}$ 直後にアプセット時の再加熱が現れ るなど，ブレーキ式摩擦圧接過程の特徽が再現されており, 


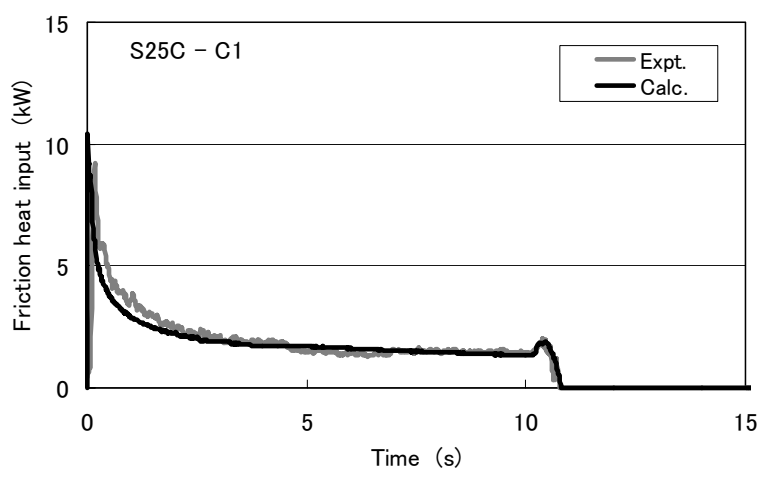

(a)

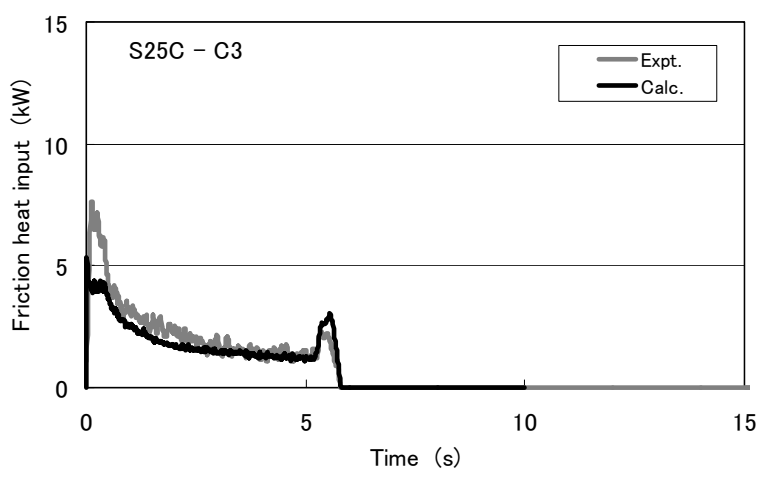

(b)

Fig.7 Comparison of measured friction heat input and calculated friction heat input: (a) S25C-C1 and (b) S25C-C3.

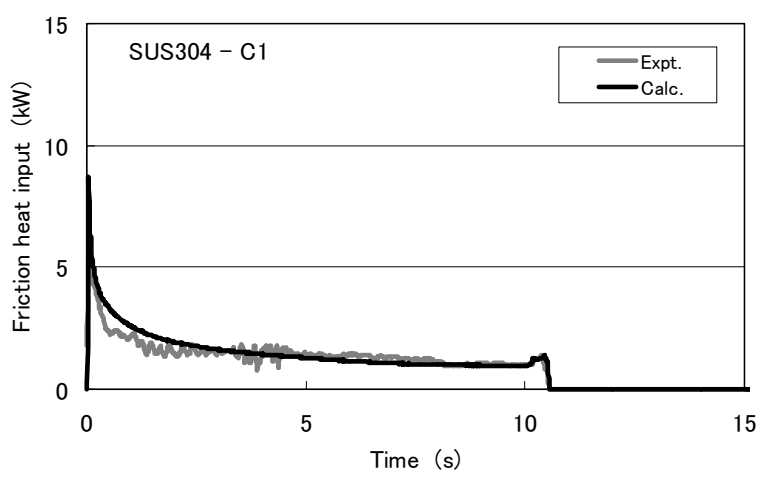

(a)

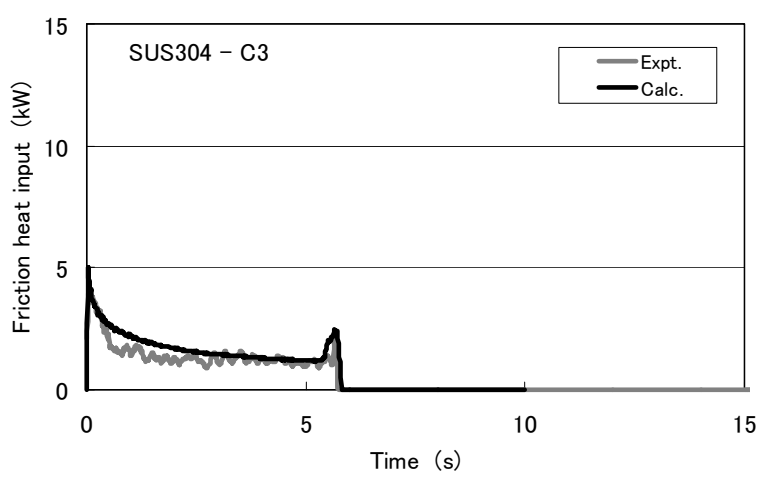

(b)

Fig. 8 Comparison of measured friction heat input and calculated friction heat input: (a) SUS304-C1 and (b) SUS304-C3.
圧接条件の違いによる入熱量の差異も含め, 計算結果は実験 結果とほぼ一致している。

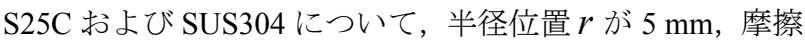
面からの軸方向距離 $x$ が 2.5, $6.5 \mathrm{~mm}$ における温度の実験結 果と計算結果を Fig.9, Fig.10に各々示す。なお，同一位置 における実験值と計算值を楕円でまとめて示している。Fig. 9(a), Fig.9(b)に示されるように, 摩擦面に近い $x=2.5 \mathrm{~mm}$ に おける温度の実験值は摩擦開始直後に上昇, アプセット開始 後の僅かな時間遅れの後に最高温度に達し, その後泠却のた め低下する。また， $x=6.5 \mathrm{~mm}$ における温度の上昇は $x=2.5$ $\mathrm{mm}$ の温度上昇に比べて緩やかであり，このような軸方向距 離の違いによる温度変化の差異が計算結果にも表れている。 また, 圧接条件が C1 である Fig.9(a) と Fig.10(a)の $x=2.5 \mathrm{~mm}$ における温度履歴を比較すると, SUS304 の最高到達温度は 実験值, 計算值ともに S25C の最高到達温度に比べ僅かに低 いことがわかる。一方, 圧接条件 C3 では, Fig.9(b)と Fig.10(b) の $x=2.5 \mathrm{~mm}$ における温度履歴に示されるように，実験值， 計算值ともに SUS304 の最高到達温度は S25C の最高到達温 度に比較し若干高くなっている。このように母材の材質の違 いによる温度履歴の差が計算結果にも現れており, 本解析方 法が妥当であることが確認できる。

半径位置 $r=5 \mathrm{~mm}$, 軸方向距離 $x=0,1,2,4 \mathrm{~mm}$ におけ る温度履歴の計算結果を S25C について Fig.11, SUS304 に ついて Fig.12 に各々示す。Fig.11, Fig.12 に示されるように，

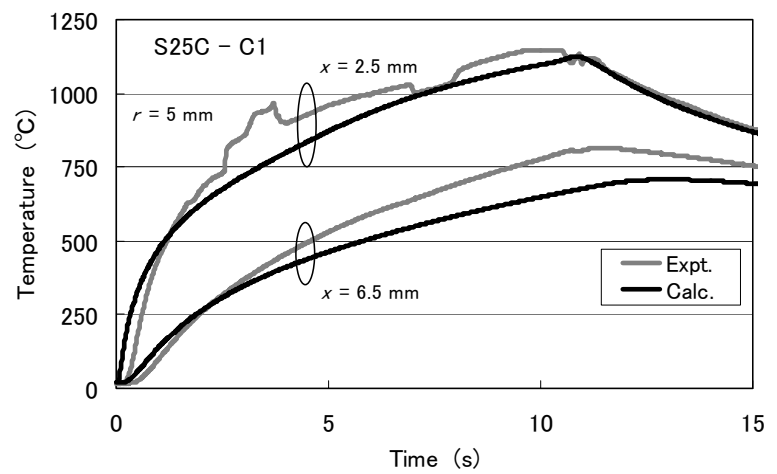

(a)

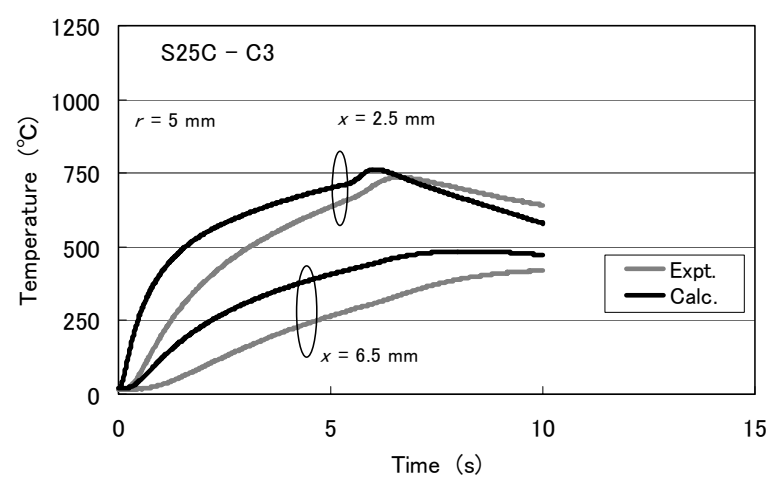

(b)

Fig.9 Comparison of measured temperature and calculated temperature at $x=2.5 \mathrm{~mm}$ and $x=6.5 \mathrm{~mm}$ : (a) S25C-C1 and (b) S25C-C3. 


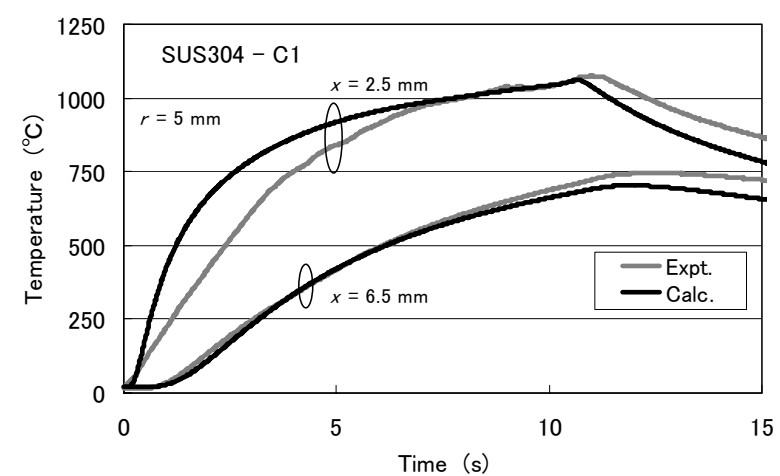

(a)

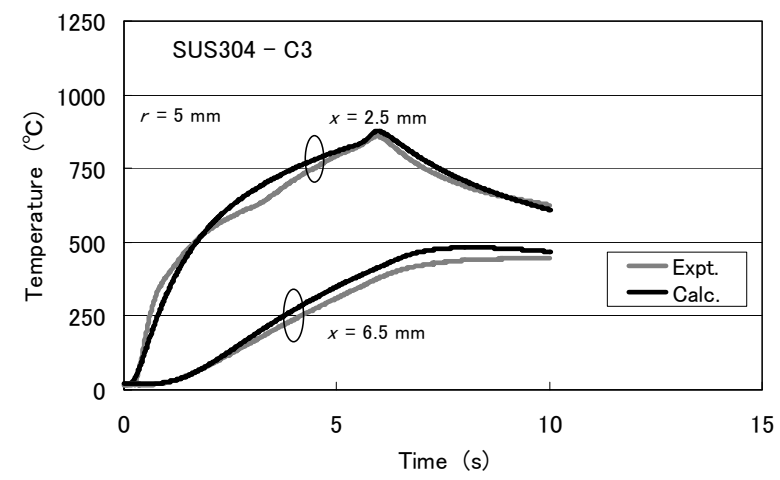

(b)

Fig.10 Comparison of measured temperature and calculated temperature at $x=2.5 \mathrm{~mm}$ and $x=6.5 \mathrm{~mm}$ : (a) SUS304-C1 and (b) SUS304-C3

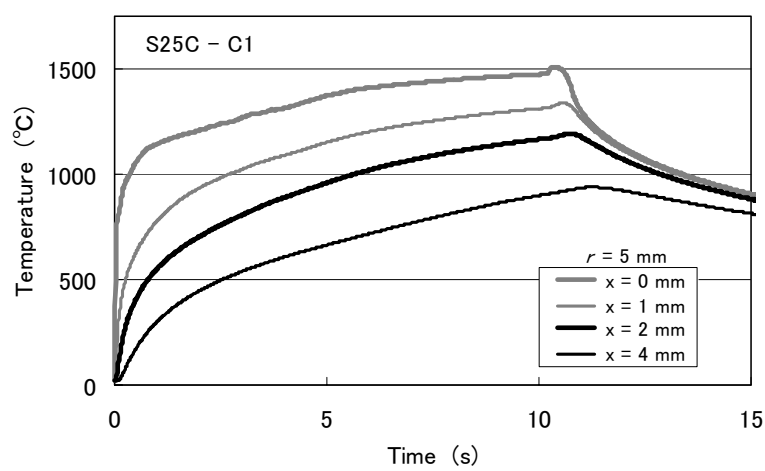

(a)

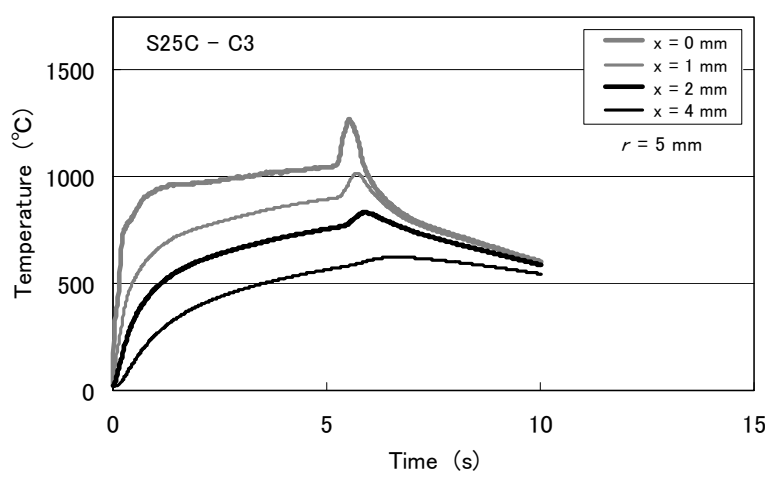

(b)

Fig. 11 Variation in calculated temperature near the friction surface: (a) S25C-C1 and (b) S25C-C3.

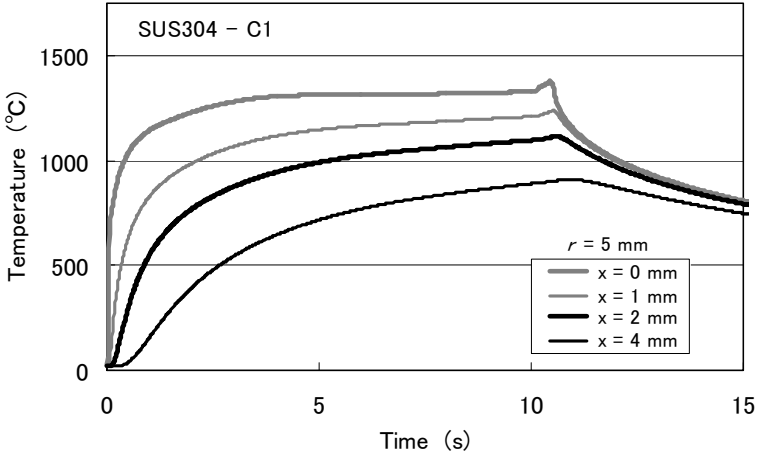

(a)

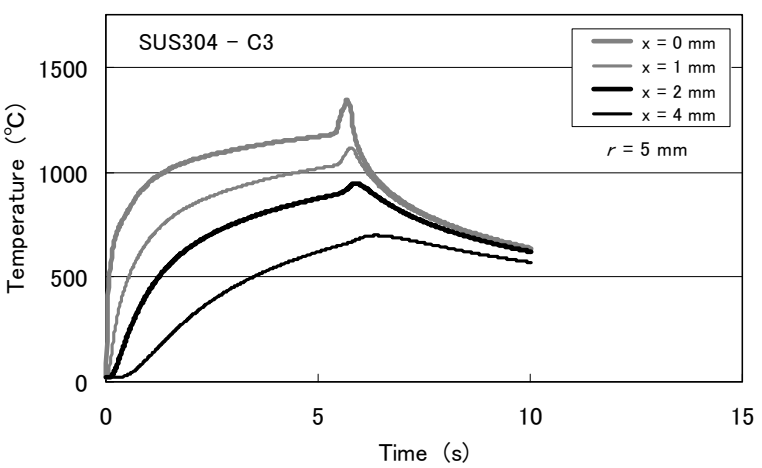

(b)

Fig.12 Variation in calculated temperature near friction surface: (a) SUS304-C1 and (b) SUS304-C3.

何れの母材, 圧接条件においても摩擦面 $(x=0 \mathrm{~mm})$ の温度 は摩擦開始後急激に上昇し,アプセット開始直後に最高温度 に達している。圧接条件 C1 の場合，摩擦時間 $t_{1}$ が長いため 摩擦面の温度はほぼ融点に達している。SUS304 の融点は S25C より低いので, Fig.11(a)と Fig.12(a)との比較からわか るように，摩擦面における SUS304 の最高到達温度は S25C より低い。一方, 条件 $\mathrm{C} 3$ では, 摩擦圧力 $P_{1}$ が低く $t_{1}$ も短い ため, 摩擦面の温度は融点に達していない。SUS304 の熱伝 導率は S25C より小さいため, 摩擦面から母材方向への熱流 束は SUS304 の方が小さくなり，この影響で Fig.11(b) と Fig.12(b)に示されるように，摩擦面における SUS304 の最高 到達温度の方が $\mathrm{S} 25 \mathrm{C}$ より高くなっている。そして, この摩 擦面における温度履歴の差異が摩擦面近傍の領域にも及んで いることがわかる。このことから，Fig.9，Fig.10において見 られる母材材質の違いによる圧接部近傍の温度履歴の差異は, 摩擦面における温度履歴の差に起因するものと推察される。

\section{2 熱影響部}

$\mathrm{S} 25 \mathrm{C}$ の圧接条件 $\mathrm{C} 1, \mathrm{C} 2, \mathrm{C} 3, \mathrm{C} 4$ について，半径位置 $r=$ $5 \mathrm{~mm}$ における温度の計算結果から求めた摩擦面近傍の最高 到達温度の軸方向分布を, マイクロビッカース硬さ分布の測 定結果とともに Fig.13 に示す。軸方向位置は摩擦開始時の 摩擦面からの距離で表している。マイクロビッカース硬さの 測定は，圧接実験終了後充分長い時間を経た後，母材軸を通 
高 温 学 会 誌 第32巻 第 4 号 $(2006$ 年 7 月)

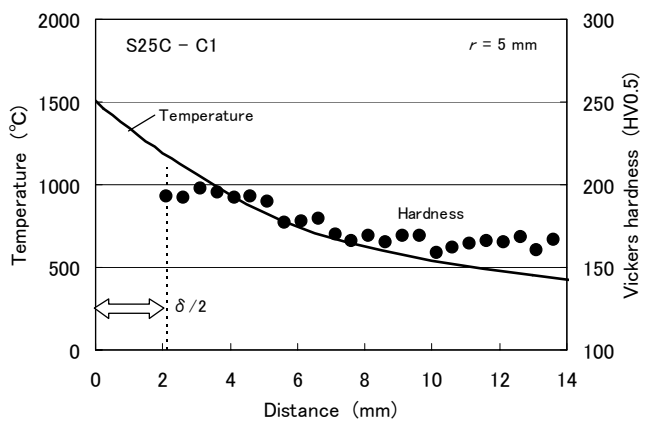

(a)

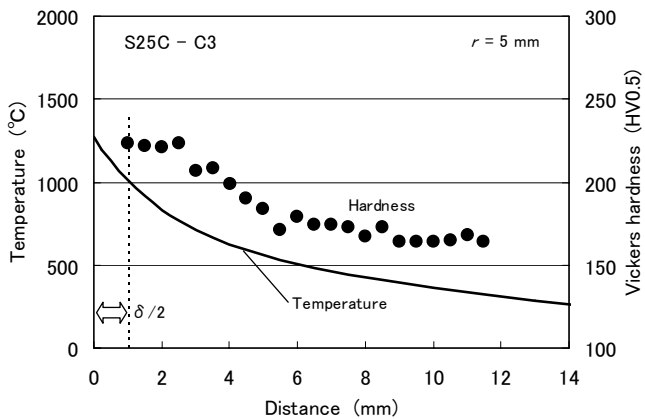

(c)

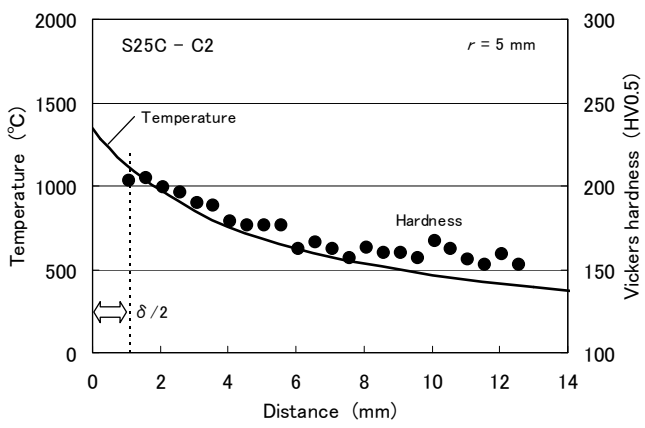

(b)

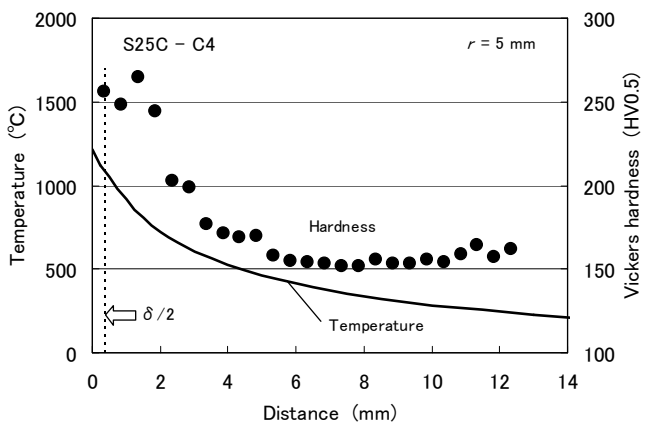

(d)

Fig.13 Maximum temperature distribution and hardness distribution (HV0.5) perpendicular to weld interface: (a) S25C-C1, (b) S25C-C2, (c) S25C-C3, and S25C-C4.

る平面で試験片を切断し, 切断面にバフ研磨を施して行った。 目視により圧接界面を確認し，この界面位置から軸方向に硬 さ分布を測定したので，Fig.13においては圧接終了時の寄り 代 $\delta$ を用いて軸方向位置を補正してある。なお，解析では母 材の変形は無視しているので, アプセットによる母材の変形 が大きい場合, Fig.13 に示す最高到達温度の分布は圧接終了 後に測定した硬さ分布と位置関係が若干ずれることになるが， 両分布を対比することにより圧接後の圧接部近傍の硬さに及 ぼす温度履歴の影響を検討することは可能と思われる。Fig. 13(a)からわかるように，圧接条件 C1 では摩擦面において約 $1500{ }^{\circ} \mathrm{C}$ である最高到達温度は，摩擦面から遠ざかるに従っ て漸次低下寸る。一方, 硬さに関しては, 摩擦面からの距離 が約 $8 \mathrm{~mm}$ より遠い領域ではほぼ一定值であるが，摩擦面に 近づくに従って硬度は次第に高くなっている。このような硬 さの変化は他の圧接条件においても同様に見られる。そして, 条件 $\mathrm{C} 1 ， \mathrm{C} 2 ， \mathrm{C} 3, \mathrm{C} 4$ の順に摩擦面の最高到達温度が低下 するとともに，例えば最高到達温度が $500{ }^{\circ} \mathrm{C}$ を越える領域 の幅は減少しており，今回の実験条件では，これに伴って硬 さの変化する領域も条件 $\mathrm{C} 1, \mathrm{C} 2, \mathrm{C} 3, \mathrm{C} 4$ の順に小さくな っている。また，圧接界面に近い部位における硬度の増加割 合は圧接条件によって異なり，条件 C4 が最も大きい。

半径位置 $r=5 \mathrm{~mm}$ における摩擦面近傍の温度履歴を Fig.14 に示寸。最高到達温度から $500{ }^{\circ} \mathrm{C}$ に至るまでの平均冷却速 度は, 条件 $\mathrm{C} 1, \mathrm{C} 2, \mathrm{C} 3, \mathrm{C} 4$ に対して各々 $31,44,74,155{ }^{\circ} \mathrm{C}$ /s であり,また, S $25 \mathrm{C}$ の $\mathrm{A}_{3}$ 変態点 $\left(830{ }^{\circ} \mathrm{C}\right)$ から $500{ }^{\circ} \mathrm{C}$ までの冷却時間は各々 $17,12 ， 6 ， 3 \mathrm{~s}$ である。CCT 線図デー
タベース $\left.{ }^{11}\right)$ にれば，炭素量 $0.15 \%$ 炭素鋼の場合， $\mathrm{A}_{3}$ 変態 点から $500^{\circ} \mathrm{C}$ までの冷却時間が約 $3 \mathrm{~s}$ 以下でマルテンサイト 変態が生じて硬度が上昇し, 炭素量 $0.3 \%$ では約 $7 \mathrm{~s}$ 以下の冷 却時間で硬度が上昇する。これらのことから， S25Cの条件 C4 において硬度の増加が大きくなるのはマルテンサイト変 態によるものと考えられる。また，条件 $\mathrm{C} 1 ， \mathrm{C} 2 ， \mathrm{C} 3$ のよう に冷却時間がより長い場合でも，CCT 線図データベースに おいてパーライト組織による硬さの変化が認められることか ら, これらの条件でも熱影響による硬さの変化が現れたもの と思われる。

SUS304 の圧接条件 C1，C2，C3，C4 について，半径位置 $r=5 \mathrm{~mm}$ における摩擦面近傍の最高到達温度の軸方向分布お よびマイクロビッカース硬さ分布を Fig.15 に示す。S25Cの

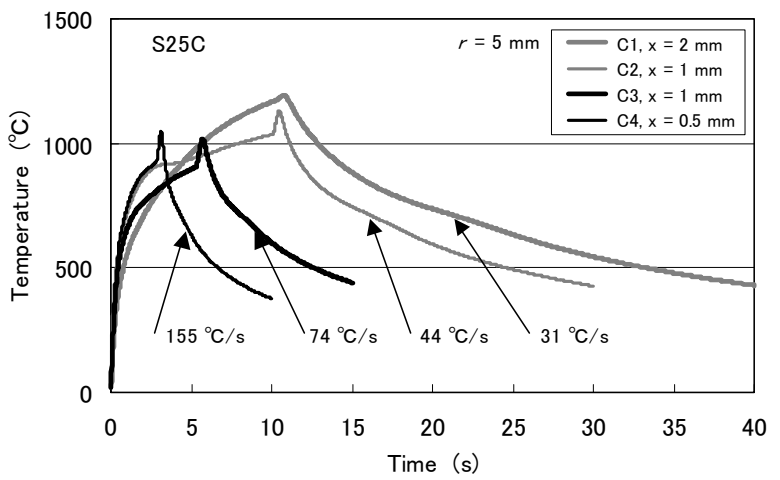

Fig.14 Variation in calculated temperature near friction surface of S25C carbon steel. 
S25C および SUS304 の同種材摩擦圧接における温度分布の数值解析 (一色・山口・川井・越智・小川)

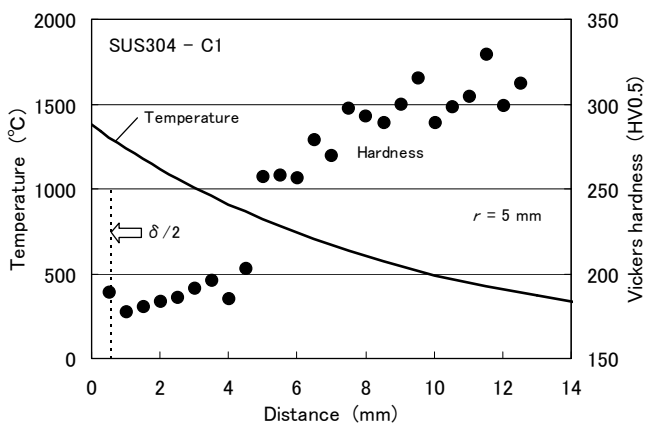

(a)

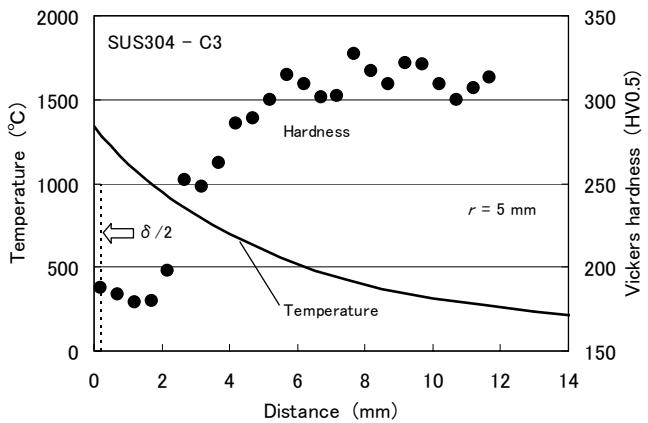

(c)

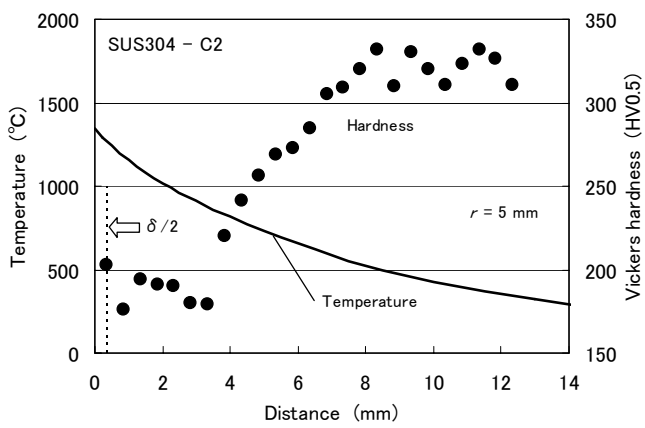

(b)

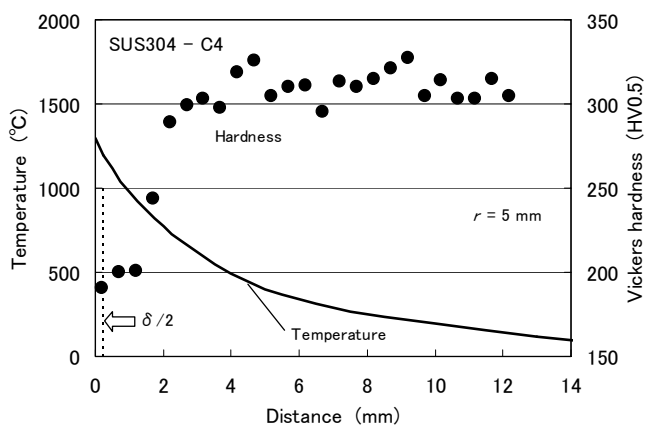

(d)

Fig.15 Maximum temperature distribution and hardness distribution (HV0.5) perpendicular to weld interface: (a) SUS304-C1, (b) SUS304-C2, (c) SUS304-C3, and SUS304-C4.

場合と同様に, 最高到達温度は摩擦面から遠ざかるに従って 漸次低下寸るとともに熱影響部において硬さが変化し,また, 熱影響部幅は最高到達温度分布に対応して条件 C1, C2, C3, C4 の順に小さくなるが, SUS304 では熱影響部の硬度は母材 硬度より低くなることがわかる。そして, Fig.16に示す圧接 部近傍 (楕円内の領域)の光学顕微鏡写真からわかるように, 圧接界面から離れた位置において観察される母材の層状組織

(繊維組織) が圧接界面では見られず，熱影響による組織の 変化が明瞭に現れている。SUS304 の場合，Fig.17 に示す半 径位置 $r=5 \mathrm{~mm}$ における温度履歴からわかるように, 平均冷 却速度は S25C と同様に圧接条件によって異なるが，母材硬 度に対する圧接界面近傍の硬度の減少割合は Fig.15 に示さ れるようにほとんど変わらない。圧接界面近傍の硬度が, 焼 きなましあるいは溶体化処理状態における SUS304 の常温ビ ッカース硬さ $\mathrm{HV}=140 \sim 190$ に近いことから，今回使用した 供試材が冷間圧延ステンレス鋼材であるため, 摩擦圧接によ る熱の影響で母材の硬度が焼きなまし状態の硬度まで低下し たものと思われる。以上のことから，温度履歴と硬さの関係 が既知であれば, 摩擦入熱モデルと非定常熱伝導解析を組み 合わせた本方法を用いることにより，摩擦面近傍における最 高到達温度分布の解析結果から熱影響部幅を推定できること が明らかとなった。

\section{5. 結言}

S25C 炭素鋼および SUS304 ステンレス鋼の同種材摩擦圧 接について, 摩擦入熱モデルと有限要素法による非定常熱伝
導解析を組み合わせる方法を用いて, 摩擦圧接過程の解析を

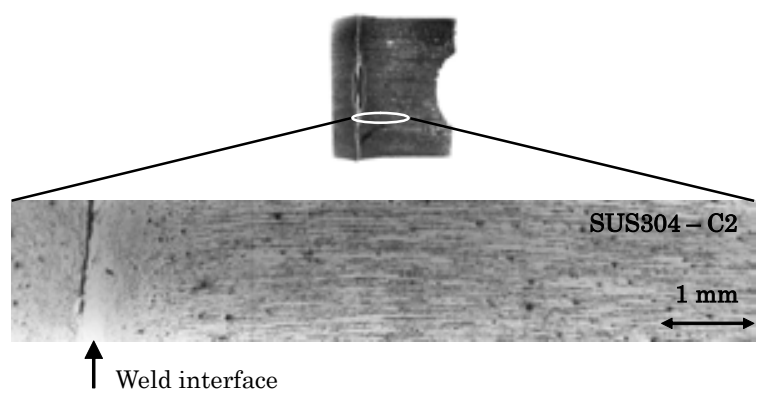

Fig.16 Macrostructure near weld interface of SUS304 stainless steel under welding condition of $\mathrm{C} 2$.

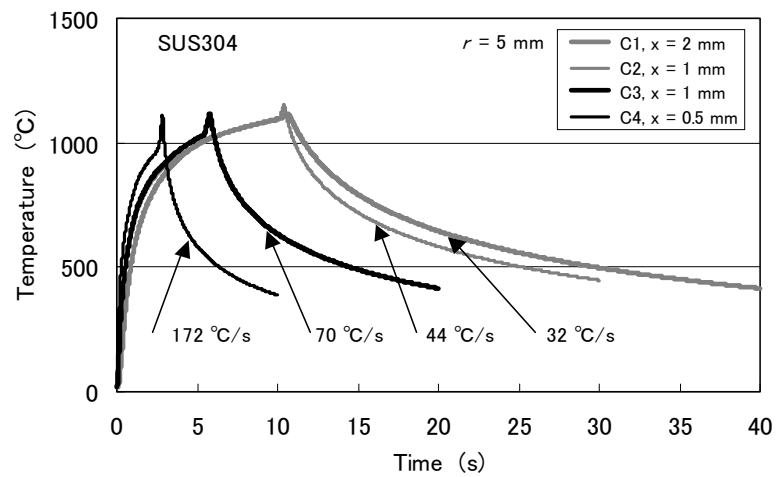

Fig.17 Variation in calculated temperature near friction surface of SUS304 stainless steel. 
行うとともに実験結果と比較した。得られた結果は以下の通 りである。

(1) 摩擦圧接時の入熱の計算結果にはブレーキ式摩擦圧接 過程の特徵が再現されており, 圧接条件の違いによる入熱量 の差異も含め, 計算結果は実験結果とほぼ一致している。

(2) 母材材質の違いによる温度履歴の差が計算結果に現れ ており，本解析方法が妥当であることが確認できた。

(3) 摩擦入熱モデルと非定常熱伝導解析を組み合わせる本 方法を用いて, 摩擦面近傍における最高到達温度分布を求め れば, 温度履歴と硬さ等の力学特性の関係を知ることにより, 熱影響部幅を推定できることが明らかとなった。

\section{引用 文 献}

1) 摩擦圧接協会編 : 摩擦圧接 (1979), コロナ社.

2) 篠田剛, 棚田和重, 加藤良久, 冷水孝夫 : 軽金属溶接, 31 (1993) $462-468$.
3）澤井猛, 小川恒一, 越智秀, 山本義秋, 古川宏之, 菅泰雄 : 軽 金属溶接, 38 (2000) 66-76.

4) 澤井猛, 小川恒一, 山口博, 越智秀, 山本義秋, 菅泰雄 : 高温 学会誌, 28 (2002) 336-343.

5) 一色美博, 山口博, 川井五作, 小川恒一: 高温学会誌, 31 (2005) 225-231.

6) 材料学会: 熱処理シミュレーションのための材料特性データベ ース「MATEQ」, 材料学会.

7) 一色美博, 山口博, 川井五作, 澤井猛, 小川恒一: 高温学会誌, 30 (2004) 279-285.

8) V.K. Lebedev, V.I. Vill and Chernenko: Avt. Svarka, 3 (1981) 1-4.

9) 菅泰雄, 小沢順一, 宮川尚吾, 小川恒一:摩擦圧接, 5 (1998) 43-50,

10) ステンレス協会, ステンレス鋼便覧(1995), 日刊工業新聞社, 147.

11）物質・材料研究機構：溶接用 C C T 線図データベース, 物質・ 材料研究機構. 